\title{
JOURNAL.RU
}

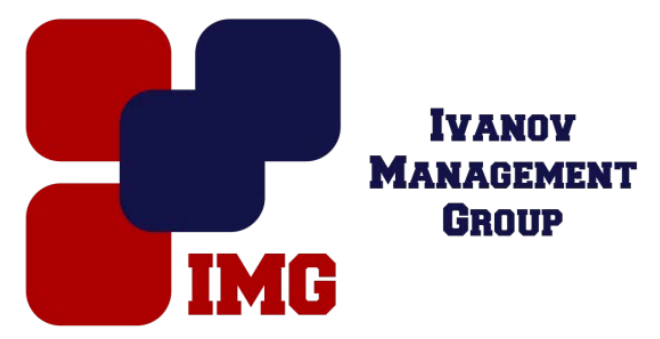

\author{
Антоненко А. А., Кабыш М. А., Можаева Н.А. \\ Брянский государственный университет имени академикаИ. Г. Петровского \\ Новозыбков, Россия
}

doi: 10.18411/lj-25-12-2016-1-01

idsp 000001:lj-25-12-2016-1-01

\section{Применение самостоятельной работы учащихся на уроках физики}

В наш век - век бурного развития науки и техники - ни одна школа не в состоянии дать человеку всех тех знаний, которые потребует от него жизнь. Но школа может привить детям необходимые навыки: умение думать, приобретать, творчески усваивать знания и применять их на практике. Вот почему инициатива и мыслительная активность учащихся становятся неотъемлемой частью современного урока, а проблема выбора форм и методов обучения не только обеспечивающих прочные знания основ наук, но и вырабатывающих навыки самообразования, является одной из актуальных проблем педагогики.

Эту проблему можно решить путем усиления самостоятельной работы учащихся во всех звеньях учебного процесса.

Под самостоятельной работой понимается такой вид мыслительной деятельности, который организуется и направляется учителем и в процессе которого учащиеся, приобретая необходимые знания и навыки, учатся наблюдать, сравнивать, сопоставлять, анализировать, обобщать, рассуждать, овладевают логическими операциями, необходимыми для самостоятельного решения вопросов, выдвигаемых жизнью.

Самостоятельная работа важнейшее условие саморегуляции личности, ее творческих возможностей. Самостоятельная работа ученика - главный путь воспитания самостоятельности. Но самостоятельная работа, привлекая современных школьников,вызывает в тоже время у многих серьезные затруднения. Она требует эмоционального, умственного напряжения, порождает массу неожиданных вопросов и ошибок, сомнения, переживания. Замечено, что особенно много затруднений возникает у ребят на начальном этапе выработки тех или иных умений и навыков, поэтому начинать эту работу надо в начальных классах.

Присутствие самостоятельной работы необходимо на уроках, в том числе и на уроках физики, так как они тренируют волю, воспитывают работоспособность, внимание, дисциплинируют учащихся. Учителю на уроках физики необходимо опираться на самостоятельную работу учеников, самостоятельное рассуждение, умозаключение. 
Самостоятельная работа - это метод, который очень помогает учителю для выяснения способностей учащихся. Работая самостоятельно, ученик должен постепенно овладеть такими общими приемами самостоятельной работы как ясное представление цели работы ее выполнение, проверка, исправление ошибок. При правильной методике организации проведения самостоятельных работ активируется умственная деятельность детей. Если детям прививать навыки выполнения самостоятельной работы и использовать на уроках различные ее виды, то у детей вырабатывается самостоятельность и развивается мышление, они стремятся выполнять более трудные задания.В процессе обучения учитель создает определенные эмоциональные отношения к знаниям. Чтобы дети любили физику и понимали ее, их нужно заинтересовать. Многие моменты самостоятельной работы можно обыграть. Игровые технологии выступают как средство побуждения, стимулирования обучающихся к учебной деятельности. Каждый игровой момент решает определенную задачу.

Например: проверку знаний обучающихся как фронтально, так и при обобщении знаний можно организовать различными играми: лапта, рыбалка, кубик, светофор, эстафета, яблоня, цветок и т.д. С учетом возрастных особенностей игровые моменты больше подходят для обучающихся 7-8 классов, но если в игру заложить материал более сложный, то старшие классы так, же будут работать активно, но с учетом следующих факторов:

- у старшеклассников более высокий уровень познавательных и практических умений;

- возрастные особенности психики и мыслительной деятельности старшеклассников;

- резко возрастающая сложность учебного материала, усиление в нем роли физической теории и математического аппарата.

Особенность федеральных государственных образовательных стандартов общего образования - их деятельностный характер, который ставит главной задачей развитие личности ученика. Современное образование отказывается от традиционного представления результатов обучения в виде знаний, умений и навыков; формулировки ФГОС указывают на реальные виды деятельности.

Самостоятельная работа-это планируемая в рамках учебного плана деятельность обучающихся по освоению содержания школьной программы, которая осуществляется по заданию, при методическом руководстве и контроле учителя, но без его непосредственного участия.

Задачи организации СР состоят в том, чтобы:

- мотивировать обучающихся к освоениюучебных программ;

- повысить ответственность обучающихся за свое обучение;

- способствовать развитию общих и профессиональных компетенций обучающихся;

- создать условия для формирования способности обучающихся к самообразованию, самоуправлению и саморазвитию.

Самостоятельная работа как форма организации обучения, возможна и необходима для получения любого образовательного результата. Однако ее виды для получения разных образовательных результатов будут различными:

- для овладения знаниями: работа со словарями и справочниками; ознакомление с нормативными документами; учебно- 
исследовательская работа; работа с конспектами лекций; работа над учебным материалом (учебника, первоисточника, статьи, дополнительной литературы, в том числе с материалами, полученными по сети Интернет); конспектирование текстов; ответы на контрольные вопросы; подготовка тезисов для выступления на семинаре, конференции; подготовка рефератов и т. д.;

- для формирования умений и владений: решение типовых задач и упражнений; решение вариативных задач и упражнений; выполнение чертежей, схем; выполнение расчётно-графических работ; решение производственных ситуационных (профессиональных) задач; проектирование и моделирование разных видов и компонентов профессиональной деятельности; выполнение курсовых и выпускных квалификационных работ; экспериментальная и конструкторская работа; упражнения на ПК и тренажёре и т. д.

Курс физики в средней школе подразумевает освоение учащимися определенного объема знаний, умений и навыков, что невозможно без самостоятельной работы. Речь идет не только о самостоятельном выполнении учащимися домашних заданий, а о самостоятельности в поисках информации, самостоятельности мышления, самостоятельности наработки навыков решения задач и т.д.

В процессе обучения физике применяются различные виды самостоятельной работы учащимися, с помощью которых они самостоятельно приобретают знания, умения и навыки.

На уроках физики можно использовать следующие виды СР:

- подбор тестовых вопросов по изучаемому явлению,

- описание явления по рисунку или схеме,

- рисование физического явления,

- вывод формулы,

- проведение научных наблюдений,

- придумывание физических вопросов,

- анализ физических ситуаций,

- установление причинно-следственных связей,

- выделение частей текста: а) обосновывающих введение понятия, б) определения, в) доказательства, г) вывод формулы и др.,

- группировка приборов, относящихся к одной теме,

- деление приборов по теме на демонстрационные и лабораторные.

На уроках физики с помощью разнообразных самостоятельных работ учащиеся могут приобретать знания, умения и навыки.

При построении системы самостоятельных работ в качестве основных дидактических требований выдвинуты следующие:

1. Система самостоятельных работ должна способствовать решению основных дидактических задач - приобретению учащимися глубоких и прочных знаний, развитию у них познавательных способностей, формированию умения самостоятельно приобретать, расширять и углублять знания, применять их на практике.

2. Система должна удовлетворять основным принципам дидактики, и, прежде всего принципам доступности и систематичности, связи теории с 
практикой, сознательной и творческой активности, принципу обучения на высоком научном уровне.

3. Входящие в систему работы должны быть разнообразны по учебной цели и содержанию, чтобы обеспечить формирование у учащихся разнообразных умений и навыков.

4. Последовательность выполнения домашних и классных самостоятельных работ логически вытекало из предыдущих и готовило почву для выполнения последующих. В этом случае между отдельными работами обеспечиваются не только «ближние», но и «дальние» связи.

Активные методы обучения это способы активизации учебнопознавательной деятельности учащихся, которые побуждают их к активной мыслительной и практической деятельности в процессе овладения материалом, когда активен не только преподаватель, но активны и учащиеся. Эти методы обучения предполагают использование такой системы методов, которая направлена главным образом, не на изложение учителем готовых знаний и их воспроизведение, а на самостоятельное овладение учащимися знаний в процессе активнойпознавательнойдеятельности

\section{Литература}

1. Л. И. Ерунова Планирование и структура современного урока физики. Л. ЛГПИ, 1985

2. Л. И. Пидкасистый Самостоятельная деятельность учащихся. - М. Просвещение, 1972

3. А. В. Усова, В. В. Завьялов Самостоятельная работа учащихся в процессе изучения физики. - М. Высшая школа, 1984

4. А.В.Усова, З.А.Вологодская Самостоятельная работа учащихся по физике в средней школе.- М.Просвещение ,1981

5. В.Г. Разумовский Развитие творческих способностей учащихся. М.Просвещение ,1975

6. И.Я. Ланина 100 игр по физике.- М.Просвещение ,1995

7. С. С. Татарченкова Урок как педагогический феномен. - С-Пб. Каро 2005 